\title{
原著
}

免疫組織染色所見からみた原発性肝癌の癌部と非癌部における アポトーシス発現程度に関する研究

\begin{tabular}{lllllll}
\multicolumn{8}{c}{ 岐阜大学第 2 外科 } \\
高 & 橋 & 禎 & 雅 & 山 & 和 也 杉 山 保 幸 \\
棠 & 喜 一 & 佐 治 重 豊
\end{tabular}

\section{Study on Apoptosis of Hepatocellular Carcinoma between Inside and Outside of Cancer Area Evaluated by Immunohistochemical Stain}

\author{
Yoshinori TAKAHASHI, Kazuya YAMAGUCHI, Yasuyuki SUGIYAMA, \\ Kiichi MIYA and Shigetoyo SAJI
}

Second Department of Surgery, Gifu University School of Medicine

原発性肝癌中, TAEによる腫瘍壊死部が比較的軽度で組織学的検索が可能であった43例を对象に, 癌部と非癌 部においてアポトーシス抑制因子からbcl-2 2 , 誘導因子からBAXとAPOP TAGを用い, その発現程度を免疫 組織学的に検索し，臨床病理学的所見，予後および既報》のp53，PCNAとの関連を比較検討した。その結果，bcl - 2 は全例陰性で, BAXは32例 (74.41\%) が陽性であった。APOP TAG AI值は癌部が非癌部に比べ有意に高 く,アルコール過飲歴有り群は癌部・非癌部とも高值を示し,アルコール過飲によりアポトーシスが促進される 可能性が示唆された。また, 腫瘍最大径が $20 \mathrm{~mm}$ 未満群のAI值は以上群に比べ有意に高值で, $20 \mathrm{~mm}$ 以上群でAI 高值群の子後は低值群に比べ有意に不良であった。以上の結果, ウイルス感染やアルコール過飲が硬変併存率や 多中心性発癌と密接に関連し,これらがアポトーシスとの関連で細胞増殖に影響を及ぼす可能性が推察された。

索引用語：アポトーシス (apoptosis), bcl-2, BAX, APOP TAG (TUNEL), 原発性肝癌 (hepatocellular carcinoma)

\section{はじめに}

本邦における原発性肝癌（以下本症）の多くは non- A, non-B型肝炎, HCVが原因ウイルスとし て注目され ${ }^{1)}$, 頻度はHBsに比べ急増傾向にあ る2)。また，本症は同時性あるいは異時性に多中心 性発癌の形態を取る場合が多く，切除範囲が転移 との関連で論議されている3)。すなわち, 本症では 非癌部でも何らかの遺伝子変異が手術時すでに存 在し, 異時性再発は転移よりも多中心性発癌によ る可能性が高いとの考之である4)。一方, 近年アポ トーシスによる枯死化現象 ${ }^{5)}$ が注目され，癌は正
常細胞が枯死化現象を失った状態と理解されてい る。すなわち, 変異型p53が発癌過程でのプロモー ションからプログレッションへの移行をアポトー シスとの関連で制御し，遺伝子の多段階変異への 進展をスイッチオンする役割を演じているとの考 えである6゙。

この観点から，われわれは教室経験例を対象に 癌部と非癌部における proliferating cell nuclear antigen (以下, PCNA) と変異型p53蛋白（以下, p53)の発現程度を免疫組織学的に検索し, 先に報 告した7)。すなわち, HCV陽性肝癌ではPCNA labeling index (以下, LI) が癌部および非癌部で 
高值を示し, p53陽性率が癌部で高值を示した, な どである。そこで，今回アポトーシス抑制因子か

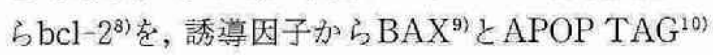
を用い, その発現程度を免疫組織学的に検索L, 臨床病理学的所見, 子後招よU゙既報 72 ○ 53 , PCNAとの関連を比較検討した。

\section{対象と方法}

\section{1. 研究対象}

対象は，1989年から 8 年間に教公で切除した原 発性肝癌95例中， transarterial embolization (以 下, TAE)による腫㾴壊死部が比較的軽度で, 組 織学的検索が可能であった43例(臨床病期；I24 例, II15例, III 2 例, 肉眼的病期：I 6 例, II26例, III11例，IV 0 例) である。なお，硬変併存肝癌で TAE非施行の 5 例と, 転移性肝癌 5 例の計 10 を対 照群として比較検討に用いた。

\section{2. 研究方法}

1) 臨床病理学的所見の検索法

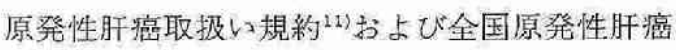
追跡調查報告 ${ }^{12)}$ に従い, アルコール過放歴の有無, ウイルス性肝炎罹患の有無, 腫痘マーカー, 腫瘍 最大径 (20 mm未満の細小肝癌と $20 \mathrm{~mm}$ 以上), 被 膜形成 (以下, fc) 々被膜浸潤 (以下, fc-inf) の 有無の 6 項目につき検討した。

2) 組織標本の作製法

手術時採取したホルマリ固定パラフィン包理ブ ロックから既報の方法7で癌部々非癌部から 4 $\mu \mathrm{m}$ の薄層切片を作製し，内因性べルオキシダー セ除去後, bcl-2 $2^{8}, \mathrm{BAX}^{91}$, APOP $\mathrm{TAG}^{(0)}$ 蛋白の 発現程度を兔疫組織学的に検索した。

3) 免疫組織染色の方法

bcl-2 : 脱パラフィン後マイタロウエーブ処理
して内因性ペルオキシターゼを不活化後, 抗馬血 清にてブロッキングしbcl-2一次抗体 (BOEHRINGER MANNHEIM社製，clone 124）を添 加後 $4{ }^{\circ} \mathrm{C}$ で 1 晚反応させた。PBSで洗浄後マウス 二次抗体で処理 L, 3,3-diaminobenzidine tetrahydrochloride (以下, DAB) で発色させ, へマト キシリンにて核染色し封入・検鏡した（Fig.1a）。

BAX：内因性ぺルオキシダービを不活化後, 山 羊血清にてブロッキングし, BAX一次抗体(N20, Working dilution $2.0 \mu \mathrm{g} / \mathrm{ml}$ ) 添加後，抗ウサギ二 次抗体を反応させ $\mathrm{ABC}$ 法にて染色し，DABにて 発色・検鏡した $($ Fig.1b)。判定は癌部と非癌部で の染色性の相対的濃度差加ら，染色性が高いもの を陽性とした。

APOP TAG : 薄層切片をProteinase Kにて蛋 白消化後，内因性ぺルォキシダーゼを除去して緩 衝液処理後，作業用TdT酵素 (S7101) を添加し $37^{\circ} \mathrm{C}$ にて 1 時間反応させた。反応停止後抗ジゴキ シゲニン・ペルォキシダーゼ処理し，DABにて染 色後methyl greenにて発色した (TUNEL染色) 。 Apoptotic Index（以下, AI）は, 細胞核 1,000 個 中の陽性細胞数から算定し陽性率で表示した

(Fig.1c)。

4) 統計学的検討の解析法

得られた測定值は，mean士standard deviation (SD) で表示し, Student's t-testにて検定した。 また，順位のないわテゴリ一変数による分析は 二乗検定老用い，累積生存率はKaplan-Meier法 にて算出した。いずれも危険率 $5 \%$ 未満を統計学 的有意差ありと判定した。
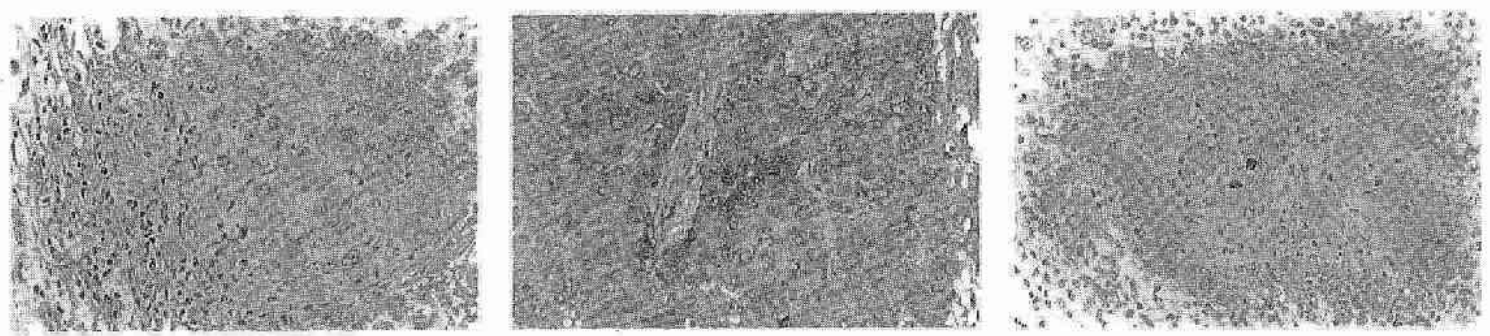

Fig. 1 The positive expression of imunohistochemical stain on bcl-2, BAX, and APOP TAG protein 


\section{結果}

\section{1. 酔床・病理学的所莡の特徽}

对象 43 例中アルコール過飲歴有りが15例, 硬変 併存が38例, HB陽性者が38例，HCV陽性者が28 例 (未検 8 例) であった。

\section{2.アポトーシス閃远蛋白の発現程度}

1 ) bcl-2：陽性細胞は，腫瘍浸潤リンパ球で観 察されたが，幹細胞や肝癁細胞にはみられなかっ た。また，非癌部でも同様に染色陽性細胞は観察 されなかった。

2 ) BAX：非癌部を染色陽性と判定すると, 癌 部では32例， $74.4 \% か ゙$ 陽性反応を示した。肝炎ウ イルスとの関連で，HB陽性例は陰性例に比べ BAXが陽性となる傾向が高く $(\mathrm{p}=0.061)$, 腫瘍マ 一カーで, PIVKA2陰性例は陽性例に比べBAXが 陽性となる傾向を示した $(\mathrm{p}=0.061)$ 。腫瘍最大径

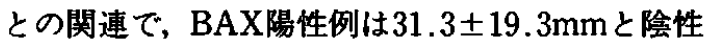

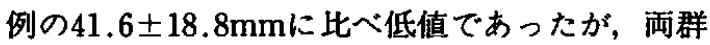
間に有意差はみられなかった。病理組織学的所見 でfc-inf(-)例は(十)例に比へBAX陽性例が有意に多 かったが $(\mathrm{p}=0.018)$ ，他の項目では各群間に有意 の関連はみられなかった (Table.1)。

3 ) APOP TAG : AI值は，癌部が $34.9 \pm 29.3$ と 非癌部の11.2 $7.7 に$ 比べ有意の高值を示した $(\mathrm{p}<0.001)$ 。また, TAE非施行例のAI值は癌部 が40.3土27.5と非癌部 $(7.9 \pm 5.3)$ に比べ有意の 高値を示し $(p=0.0363)$ ，転移性肝癌例でも祦部

(15.3土19.1) は非癌部 $(4.5 \pm 3.5)$ に比べ高値 を示したが有意差はみられなかった。なお，癌部 ではTAE非施行例が，非癌部ではTAE施行例が 最も高いAI值を示し, 転移性肝癌症例では癌部・ 非癌部とも最も低い值を示した（Table. 2)。

\section{3. bcl-2, BAX, APOP TAGとの间}

1 ) bcl-2染色：全例染色陰性のため比較検討は 不能であった。

2) BAXとAPOP TAG AI值との関連：BAX 陽性例のAPOP TAG AI值は $36.2 \pm 28.8$ と陰性

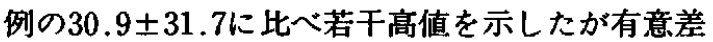
はみられなかった (Table.3a)。

3）アルコール過郋歴との関連：AI值は癌部で 過飲歴有り群が $41.3 \pm 29.1$ と無し群の $31.4 \pm 29.3$
に比べ若干高値を示し，非癌部では過飲歴有り群


示す傾向がみられた $(p=0.053$, Table.3b)。

4 ) 腫瘍最大径との関連：AI值は癌部では腫煬 径が $20 \mathrm{~mm}$ 末满で $44.8 \pm 30.1$ と $20 \mathrm{~mm}$ 以上の $30.9 \pm 27.3$ に比べ若干高值を示し，非癌部では両

Table. 1 The rate of positive expression of $\mathrm{BAX}$ protein by immunohistochemical stain according to clinico-pathological findings

\begin{tabular}{|c|c|c|c|c|}
\hline & & positive & negative & p- \\
\hline cases & & $32(74.4 \%)$ & $11(25.6 \%)$ & \\
\hline alcohol & yes & 13 & 2 & \\
\hline & no & 19 & 9 & $p=0.178$ \\
\hline cirrhosi & s yes & 28 & 10 & \\
\hline & no & 4 & 1 & $p=0.761$ \\
\hline$\overline{\mathrm{HB}}$ & positive & 30 & 8 & \\
\hline & negative & 2 & 3 & $p=0.061$ \\
\hline $\mathrm{HCV}$ & positive & 19 & 9 & \\
\hline & negative & 5 & 2 & $p=0.856$ \\
\hline$\overline{\mathrm{AFP}}$ & positive & 18 & 9 & \\
\hline & negative & 13 & 2 & $p=0.158$ \\
\hline$\overline{\text { PIVKA2 }}$ & 2 positive & 10 & 7 & \\
\hline & negative & 18 & 3 & $\mathrm{p}=0.061$ \\
\hline CEA & positive & 7 & 2 & \\
\hline & negative & 25 & 9 & $p=0.795$ \\
\hline max.dia & meter & $31.3 \pm 19.3$ & $41.6 \pm 18.8$ & $p=0.220$ \\
\hline fc & positive & 25 & 10 & \\
\hline & negative & 7 & 1 & $p=0.347$ \\
\hline fc-inf & positive & 13 & 9 & \\
\hline 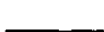 & negative & 19 & 2 & $p=0.018$ \\
\hline
\end{tabular}

Table. 2 The comparison of APOP TAG apoptotic index (AI) between in the cancer area and out of cancer area

\begin{tabular}{lccc} 
& in cancer & out of cancer & $\mathrm{p}$-value \\
\hline cases $(n=43)$ & $34.9 \pm 29.3$ & $11.2 \pm 7.7$ & $\mathrm{p}<0.001$ \\
without TAE $(n=5)$ & $40.3 \pm 27.5$ & $7.9 \pm 6.3$ & $\mathrm{p}=0.0363$ \\
metastatic liver $(n=5)$ & $15.3 \pm 19.1$ & $4.5 \pm 3.5$ & $\mathrm{p}=0.203$ \\
\hline
\end{tabular}

Table. 3 The comparison of APOP TAG apoptotic index (AI) between the cancer area and out of one according to clinicopathological findings

a) between APOP TAG AI and BAX stain

\begin{tabular}{cccc} 
& positive & negative & p-value \\
\hline BAX & $36.2 \pm 28.8$ & $30.9 \pm 31.7$ & $p=0.607$ \\
\hline \multicolumn{2}{l}{ in out of cancer area, all samples showed positive stain }
\end{tabular}

b) between APOP TAG AI and clinico-pathological findings

\begin{tabular}{cccc} 
& & in cancer & out of cancer \\
\hline alcohol & positive & $41.3 \pm 29.1^{\mathrm{a}}$ & $14.3 \pm 9.0^{\mathrm{s}}$ \\
& negative & $\left.31.4 \pm 29.3^{\mathrm{b}}\right)$ & $9.5 \pm 6.5^{\mathrm{d}}$ \\
\hline diameter & $<20 \mathrm{~mm}$ & $\left.44.8 \pm 30.1^{\mathrm{e}}\right)$ & $12.8 \pm 10.3^{\mathrm{b}}$ \\
$\geqq 20 \mathrm{~mm}$ & $30.9 \pm 27.3^{\mathrm{D}}$ & $\left.11.0 \pm 4.8^{\mathrm{b}}\right)$ \\
\hline
\end{tabular}

a)-b) $: p=0.293, c) \cdot d): p=0.053 、 e)-f): p=0.203$,

g)-h) : $\mathrm{p}=0.575$ 
群間に差はみられなかった (Table.3b)。

5) 肉眼的病期進行度との関連：Stageの進行 に伴ってAI值は低下し, 各群癌で有意差が観察さ れた (Table.3c)。

\section{4. 予後との関連}

$\mathrm{AI}$ 值が34.8以上を高值 (以下, H) 群, 未満を 低值 (以下, L) 群に分けると, H群はL群に比べ 有意に予後不良であった $(\mathrm{p}=0.007$, Fig, 2)。腫 瘍最大径との関連では, $20 \mathrm{~mm}$ 以上群でH群が L 群 に比へ有意に予後不良であったが $(\mathrm{p}=0.046, \mathrm{Fig}$. 3a)，未満群てL群に癌死例はなく，H群で比へ子 後良好であった（Fig.3b)。

\section{考察}

細胞注界からの様々な刺澈を受け，増殖，分

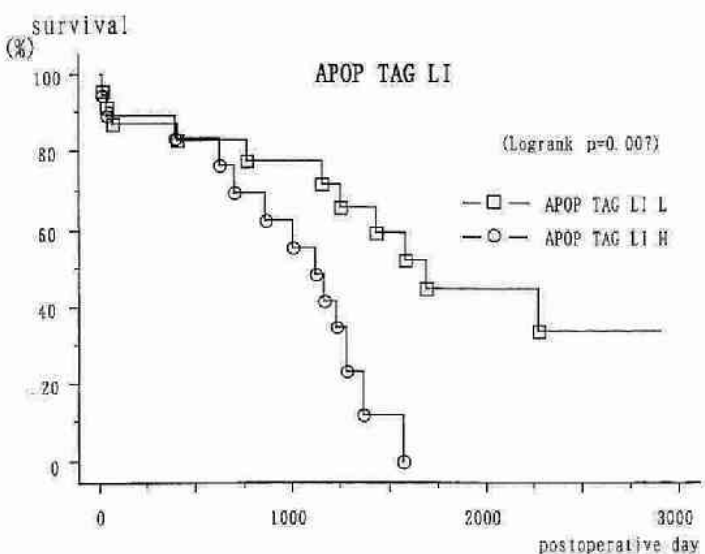

Fig. 2 The comparison of survival curves between the high APOP TAG apoptotic index (AI) ( $\geqq 34.8$ ) and the low $\mathrm{Al}(<34.8)$

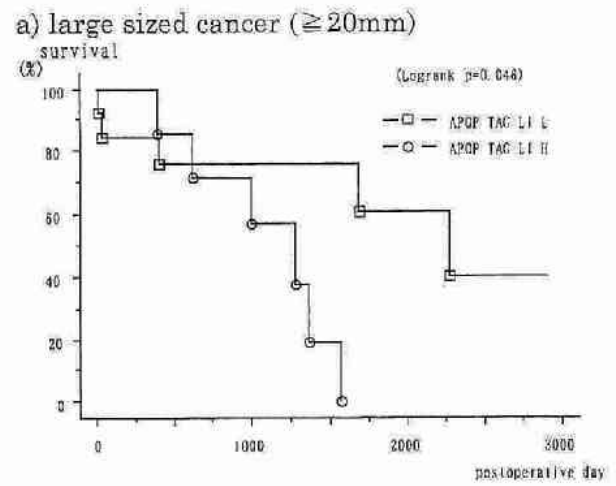

化，死滅，などの反応が意起する。この中で細胞 死には壞死と枯死が存在するが，後者は発生過程 における形態形成や,成熟個体における細胞交替, 内分泌系に㧍ける恒常性の維持, 免疫系の特異性 と多様性の成立など，生命機能維持に不可欠な細 胞消去機構として存在している ${ }^{13)}$ 。この枯死化現

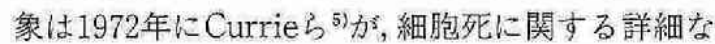
病理学的所見から組織内の特定の細胞が壞死とは 異なった特徴的な形態变化をきたして散在的に死 滅するのをギリシャ語の「木の葉や花びらか離れ 落ちる」意からapo (離れる) と ptosis (落ちる) を合わせアポトーシス (apoptosis) と名付けた。 一方，壊死 (ネクローシス) は細胞が膨張して細 胞膜が破壊され，細胞内顆粒などの内容物を放出 し炎症反応が意起される受動的な死であるが，ア ポトーシスでは細胞膜は破壞されずにミトコンド リアなどの細胞内顆粒はそのままに, DNAと核と 断片化とアポトーシス小体が形成される。これは マクロファージなどの舍食細胞に処理されるため 炎症反応が少なく、高度な制御機構のもとに行わ れる能動的な自己破壊と考之られている5)。

ところで，遺伝子の多段階変異を伴う癌の堌殖 は, 正常細胞のアポトーシスからの回避現象によ ると考えられるようになり，プロモーションから プログレッションの過程でp53を介したアポトシ 又制御機構の破綻が注目されている。そ己で，著 者らは肝炎ビールスを誘因とする原発性肝癌症例 で，癌部と非癌部におけるアポトーシス発現の有 無を免疫組織学的に㭘索し, 多中心性発嵒の可能 性を推察したわけである。

(\%) ${ }^{\text {s. }}$

$$
\text { b) small sized cancer }(<20 \mathrm{~mm})
$$

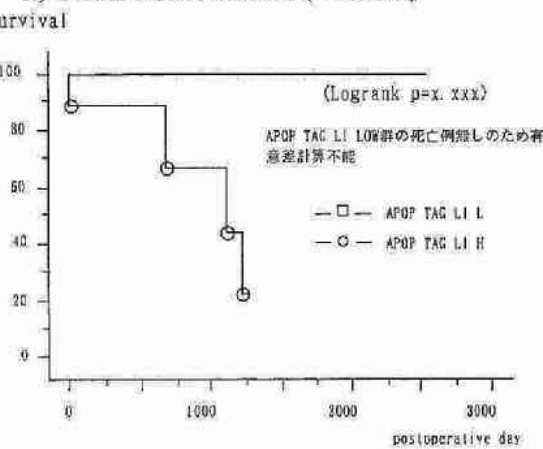

Fig. 3 The comparison of survival curves between the high APOP TAG AI ( $\geqq 34.8)$ and the low $\mathrm{Al}(<34.8)$ according to maximum tumor diameter 


\section{1.アポトーシス関連蛋白の発現状況}

アポトーシス抑制遺伝子であるbcl-2蛋白の発 現は, 癌部・非癌部とも観察されず, 誘導因子で あるBAXは, 非癌部を全例染色陽性と判定すると 癌部では74.4\%が陽性であった。臨床病理学的所 見では，BAXはHB陽性例，KIVKA2陰性例，腫 瘍径が小さく, fc-inf(-)例に頻度が高かった。すな わち, $20 \mathrm{~mm}$ 未満の細小肝癌は早期癌に近く, HB 陽性例は腫擅増殖が緩慢 ${ }^{14)}$ と推察されているの でかかる症例でBAX陽性例が多かった結果は了 解可能と思われる。

ところで, BAXはbcl-2を含むサブファミリー のうち第二ファミリーに属し，へテロ二量体を形 成してBAX-BAXのホモタイマーを形成するこ とによりアポトーシスを誘導すると考之られてい る ${ }^{9 !}$ 。一方, BAXとbcl-2では二つの共通領域は比 較的保たれているか，アミノ酸配列の全体的な相 同性が低く, 肝, 脺, 督などではBAXは広範囲に 存在するが, bcl-2は欠如していると考えられてい る ${ }^{15)}$ 。それゆえ, 著者らの検索でもbcl-2は肝浸潤 リンバ球に僅かに観察されたが, 肝細胞や肝癌で は染色㓌性であったものと考えている。

APOP TAGは, アポトーシスの簡便な検查法 としてのTUNEL法でDNA3'-OH木端をbiotindUDPとTdTを用いて標識することによって判定 可能で10), 今回同様手技で検索した。その結果, AI 值はTAE施行の有無に関わらず, また転移性肝癌 症例でも癌部が非癌部に比へ高值を示し，その程 度は癌部ではTAE非施行例で最高值を, 転移性肝 癌例で最低值を示した。腺腫の異型度別分類でア ポトーシスは, 低異型度より高異型度で有意に高 く, 増殖活性も同様に高異型度群で高值を示す場 合が多い ${ }^{16)}$ 。この所見は一見矛盾してみえるが, 高 異型度腺腫では低異型度腺腫に比べDNA障害が 頻発し、より多くの細胞がアポトーシスにより排 除された結果と考之られる。自験例でもAI值は癌 部で高值を示したが,この理由も同様機序による と推察している。一方, TAE非施行例で高值を示 した理由は, TAEでは壊死が主体で周辺部の枯死 化細胞已 3 週間以上の手術待機中に会食・処理さ れ,結果的にTAE群でAI值が低かったと推察して いる。また, TAEによる影響は今回の腫陽周辺部
での検索では無視可能と思われた。

\section{2、各種アポトーシス関連因子での検索結果}

先ず, BAXとAPOP TAGとの関連で, BAX陽 性例のAI值は陰性例に比べ若干高值を示したが 有意差はみられなかった。アルコール過飲歴との 関連では過钦歴有り群のAI值は癌部で若干高く 非癌部で高值を示す傾向がみられたか，腫瘍径別 でAI值は癌部で $20 \mathrm{~mm}$ 未満群が以上群に比べ若干 高値を示した。肉眼的病期ではAI值はStage I が 最も高く, StageIIIか最も低かった。予後は, AI高 值群が低值群に比へ，腫瘍最大径が $20 \mathrm{~mm}$ 以上群 ではAI高值群が低值群に比べ共に有意に不良で あった。この結果から, 細小肝癌やStageの低い例 でアポトーシスの頻度が高く，アルコール過飲は 非癌部でのアポトーシスを促進する可能性が示唆 された。後者はアルコールがDNA障害を促進し, 結果的にアポトーシスに宿る細胞を増加させた可 能性と, 非癌部での多段階変異をアルコールが抑 制した可能性が推察される ${ }^{17)}$ 。そこで, 先に報告》 したPCNA AI值, p53陽性率とアポトーシスとの 関連を検討した。その結果, BAX陽性群のPCNA LI值は除性群に比べ低值で, APOP TAG AI值と LI值は有意の逆相関を示し, AI 高值例ではLI值が 低值を示し細胞増殖能が抑制されている可能性が 示唆された (Fig. 4)。一方，アルコール過飲歴と の関連では, 過飲歴有り群のLI值は癌部, 非癌部 とも有意に低值で，AI值はともに高值を示し，と くに非癌部で有意差がみられた。この結果は、ア

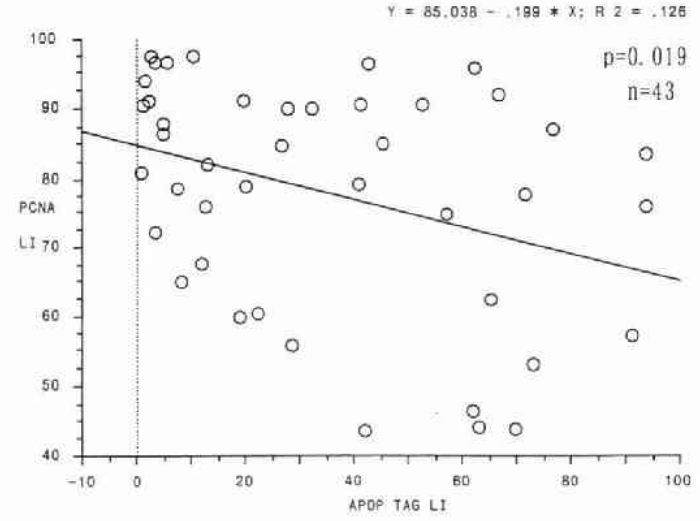

Fig. 4 Correlation between PCNA labeling index and APOP TAG apoptotic index of the patients with hepatocellular carcinoma. 
ルコール過飲により肝細胞の增殖活性が低下し, アポトーシスを誘導する可能性が示唆されたわけ である。また，非癌部でその傾向が強かったこと より, 硬変併存肝癌例での術後アルコール過飲は, アポトーシスを促進することにより增殖活性を低 下させ, 残肝の遺伝子変異を抑制して多発癌の発 生を防止できる可能性が示唆されたが，同様所見 の報告はない。

変異型p53は，BAX陰性例で陽性となる傾向が 示唆されたが, AI值はp53陽性例と陰性例の間に 差はみられなかった(Table.4)。すなわち, p53陽 性肝癌はBAX染色が陰性で, BAX陰性例ではLI 值が高く， AI值が低値を示す傾向がみられた。以 上の結果, BAX陰性例ではp53によるアポトーシ スの誘導が抑制され、細胞増殖活性が充進したと 推察されたが, p53によるアポトーシス誘導は BAXのみによるものではなく，BAX欠損マウス でも $\boldsymbol{\gamma}$ 線照射によりアポトーシスが発生すること より18),アルコール過飲とアポトーシスとの関連 は襩雑と思われる。

\section{3. 予後との同について}

$\mathrm{AI}$ 高值群の生存由線は低值群に比べ有意に不 良で, 高頻度アポトーシス群は逆に細胞增殖が高 く, DNA障害の頻度も高く, 結果的に予後不良に なったと推察された。また, $20 \mathrm{~mm}$ 以上の肝癌では $\mathrm{AI}$ 高值群の予後は低值群に比べ有意に不良であ ったが, 20mm未満の細小肝癌ではAI值と予後と の間に有意の関連はみられなかった。肝癌の進行

Table. 4 Relationship between apoptotic activity evaluated by BAX and APOP TAP Al and the activity of cancer proliferation by PCNA LI and p53 using immunohisto chemical stain

a) BAX and cancer proliferation

\begin{tabular}{cccc}
\multicolumn{5}{c}{ positive BAX } & negative BAX \\
\hline PCNA LI & $75.3 \pm 16.9$ & $86.2 \pm 12.0$ & $\mathrm{p}=0.057$ \\
\hline p53 positive & 7 & 5 & \\
negative & 25 & 6 & $\mathrm{p}=0.133$ \\
\hline
\end{tabular}

b) APOP TAG AI and cancer proliferation in the cancer area

\begin{tabular}{|c|c|c|c|}
\hline & positive p53 & negative 053 & \\
\hline AI value & $33.2 \pm 29.4$ & $35.5 \pm 29.7$ & $p=0.819$ \\
\hline & high PCNA & low PCNA & \\
\hline AI value & $28.7 \pm 27.4$ & $45.1 \pm 30.3$ & $p=0.077$ \\
\hline
\end{tabular}

c) APOP TAG AI and cancer proliferation in out of cancer area \begin{tabular}{lccc} 
& high PCNA & low PCNA & \\
\hline AI value & $9.6 \pm 5.6$ & $14.0 \pm 10.0$ & $\mathrm{p}=0.069$ \\
\hline
\end{tabular}
に伴いAI值が增加する一見矛盾した現象は, 癌遺 伝子変異のみならず宿主由来の様々な抑制因子が 複雑に関与している可能性が推察される。それゆ 之, 原発性肝癌の切除標本を用いたPCNA，p53， bcl-2, BAX, APOP TAGの検索は, 癌の悪性度 や残肝再発の予測に有用ではあるが，各病期によ ク様々な反応を示すため、結果の判読には注意を 要するものと思われた。

\section{結語}

1989年から 8 年間の間に肝切除した原発性肝癌 中, TAEによる腫瘍壊死部が比較的軽度で組織学 的検索が可能であった43例を对象に，癁部と非癌 部でbcl-2, BAX, APOP, TAG蛋白の発現程度 を免疫組織学的に検索し, 臨床病理学的所見や予 後との関連を比較検討した。

その結果, bcl-2は全例陰性で, BAXは32例 (74.41\%) が陽性であった。APOP TAG AI值 は癌部が非癌部に比べ有意に高く、アルコール過 飲歴有り群は癌部・非癌部とも高值を示し、アル コール過的によりアポトーシスが促進される可能 性が示唆された。また, 腫瘍最大径が $20 \mathrm{~mm}$ 未满群 のAI值は以上群に比へ有意に高值で，20 $\mathrm{mm}$ 以上 群でAI高值群の予後は低値群に比べ有意に不良 であった。

以上の結果, ウイルス感染やアルコール過觓が 硬変併存率や多中心性発癌と密接に関連し,これ らがアポトーシスとの関連で細胞增殖に影響を及 ばす可能性が推察された。

\section{卷考文献}

1）小俣政男：日本の肝癌。外科治療 $73: 487-492$, 1995

2) Takano S, Yokosuka O, Imazeki F, et al : Incidence of hepatocellular carcinoma in chronic hepatitis B and C:A prospective study of 251 patients. Hepatology $21: 650-655,1995$

3）小智男, 高山忠利, 山本順司他：肝切除後の残 肝再発。外科 $57: 1306-0309,1995$

4) Belghiti J, Panis Y, Farges O, et al : Intrahepatic recurrence after resection of hepatocellular carcinoma complicating cirrhosis. Ann 
Surg 214 : 114-117, 1991

5) Kerr JFR, Wyllie AH, Currie AR : Apoptosis : A basic biological phenomenon with wideranging implications in tissue kinetics. $\mathrm{Br} \mathrm{J}$ Cancer $26: 239-257,1972$

6) Vogelstein B, Kinzler KW : p53 function and dysfunction. Cell $70: 523-526,1992$

7）高橋禎雅，若原正幸，梅本敬夫他：PCNA と変異 型p53の免疫組織学的所見からみた原発性肝癌に おける癌部と非癌部の特徽について. 日外科系連 会誌 $23: 795-802,1998$

8) Tsujimoto $Y$, Croce $C M$ : Analysis of the structure, transcripts, and protein products of $\mathrm{Bcl}-2$, the gene involved in human follicular lymphoma. Proc Natl Acad Sci USA $83: 5214$ $-5218,1986$

9) Oltvai $\mathrm{ZN}$, Milliman CL, Korsmeyer SJ : Bcl-2 Heterodimerizes in vivo with a conserved homolog, Bax, that accelerates programed cell death. Cell $74: 609-619,1993$

10) Gavrieli $Y$, Sherman $Y$, Ben-Sasson $S A$ : Identification of programmend cell death in situ via specific labeling of nuclear DNA fragmenta. tion. J Cell Biol $119:$ 493-501, 1992

11）日本肝癌研究会：原発性肝癌取り扱い規約, 改訂 第 3 版．東京，金原出版，1992，p16-39
12）日本肝癌研究会：原発性肝癌に関する追跡調查 一第11報一。肝脿，36：208-218，1995

13) Williams GT, Smith CA : Molecular regulation of apoptosis: genetic controls on cell death. Cell 74 : 777-779, 1993

14) Oka H, Kurioka $N$, Kanno $T$, et al : Prospective study of early detection of hepatocellular carcinoma in patients with cirrhosis. Hepatology $12: 680-687,1990$

15) Krajewsik S, Krajewska M, Shabaik A, et al : Immunohistochemical determination of in vivo distribution of $\mathrm{Bax}$, a dominant inhibitor of $\mathrm{Bcl}$ -2. Am J Pathol 145 : 1323-1336, 1994

16) Arai $T$, Kino $I$ : Role of apoptosis in modulation of the growth of human colorectal tubular and villous adenomas. J Pathol $176: 37-44$, 1995

17) Yamauchi $M$, Nakahara M, Maezawa $Y$, et al : Prevalence of hepatocellular carcinoma in patients with alcoholic cirrhosis and prior exposure to hepatitis C. Am J Gastroenterology $88: 39-43,1993$

18) Kundoson CM, Tung KSK, Tourtellotte WG, et al : Bax-deficient mice with lymphoid hyperplasia and male germ cell death. Science 270 : 96-99, 1995 